\title{
Assessment Strategies And Feedback Practices By College Instructors: A Cross-Sectional Study Mario ColegaOli
}

Cagayan State University, Carig Campus, Tuguegarao City 3500, Cagayan Valley Philippines, mariooli299@gmail.com

\section{ABSTRACT}

This paper described the different classroom assessment strategies, determined the extent of implementation of feedback and tested the differences between respondentsclassification group on the feedback practicesimplemented by the College Instructors on the class performance of their students.It made used of quantitative-descriptive and cross-sectional research design. The data were provided by 51 Instructors chosen systematically and 312 IT students selected through stratified sampling. The findingsreported that the instructors have always practiced the giving of class recitation, seatwork and teacher-made quiz in which these were confirmed by their students' responses.After these assessments were evaluated, the Instructors have always provided feedback as they promptly return the papers of their students to correct major issues or misconceptions and to serve as guide for students on where to go next and what to focus on. Further, they too provide feedback orally to the whole class when there is so much information for them to read. Moreover, the Instructors regardless of employment status and subject taught have the same feedback practices despite that not all of them have earned Education units. This best practices of the Instructors in using different assessment strategies and the provision of feedback have contributed to the academic achievement of the students as this will guide not only them but more so their students, on what to improve and focus on. Among all the factors for an effective feedback, timeliness has always been practiced by all the IT Instructors.However, the extent of implementation of giving feedback practiced by Non-major Instructors as assessed by students and self-rating of Non-major Instructors, and the evaluation of the feedback practices made the Non-major and major Instructors are statistically significant.Hence, a deeper investigation is needed to confirm the present finding as regards the differences on the implementation of feedback by the Major and Non-major Subject Instructors in Information Technology.

Keywords: Assessment strategies, formative assessment, feedback practices, feedback

Article Received: 10 August 2020, Revised: 25 October 2020, Accepted: 18 November 2020

\section{Introduction}

One of the most important factors to consider on the achievement of a learner in the classroom is receiving a feedback from any assessment he or she has been engaged with. This information provides signal as to stay on focus or to move on to the next level in the activity, topic or course. According to
Subheesh\&Sethy (2020), assessment and feedback are crucial in the teaching and learning process because they are integrallyentrenched in the course curriculum.

\section{Assessment}


The process of gathering information and interpreting evidence to make judgements about student learning is called assessment. It is the crucial link between learning outcomes, content and teaching and learning activities because the result obtained through it determines the effectiveness of the activities in achieving the supposed learning outcomes.Consequently, it is the deciding factor (Reganit, Elicay and Laguerta, 2010) as to where the students are at in their learning, where they need to go, and how best to get there.

In addition, assessment is a full range of information gathered and synthesized by teachers about their students and their classrooms which can be obtained in informal ways, such as observation or verbal exchange and in formal ways such as assignments, tests, and written reports or outputs (Garcia, 2008). It is further explained that the concern of assessment is on how much change that has occurred on the students' acquisition of a skill, knowledge or value before and after a give learning experience. It also provides valid evidence of learning achievement to inform students, to facilitate provisions of further learning or to certify that a required level has been reached (Niss, 1993).

\section{Formative assessment}

Instructors or teachers typically collect information about student progress through various formative assessment strategies. Formative assessment is done in the classroom during the learning process and it allows instructors to collect data regarding where the students are relative to the goal of the lesson. It also includes assessment as learning, where students reflect on and monitor their own progress. The information gained guides teachers' decisions on how to enhance teaching and learning. Formative assessment enables students to learn through the process of feedback and opportunities to practice and improve. As students reflect on and monitor their progress this process effectively becomes assessment as learning and contributes to students planning future learning goals. (http://ais.act.edu.au/wpcontent/uploads/2016/02/Teachers-Guide-

To-Assessment.pdf)

Instructors can then use this information to provide feedback to each student in a way that is specific to that student. Thus the feedback is individualized, relevant, and appropriate for where the student currently is in their learning.

\section{The Cycle of Formative Assessment}

Figure 01 illustrates the process in conducting a formative assessment in the classroom. There are four steps: goals(objectives), instructions(delivery), measuring(assessment), and feedback. The goals or objectives must be set so that there are specific guides in giving instruction. The instruction is a medium to deliver what is ought to be delivered to students in relation to the subject matter on hand. It is where the goal is being implemented. In order to determine whether or not the content is delivered effectively to the learners, the teachers would conduct an assessment during the instruction.

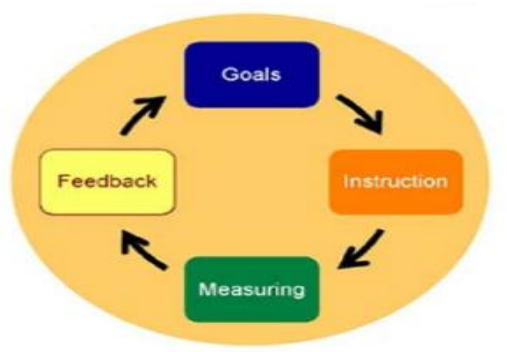

Fig. 01. The Process of Formative Assessment 
So that the teacher would whether to move forward if the result of assessment meets the required level of standard or to provide additional work to be assessed to strengthen the skills of the students.

However, the result of assessment obtain by the teacher from the assessment must be properly communicated to the concerned students in the form of feedback. With this action, both the teachers and students are aware of has been transpired during the delivery of the lessons.

\section{Assessment Strategies}

Various strategies in formative assessment have been recorded but below are just few of them. These include the following: anecdotal records (objective narrative records of student performances, strengths, needs, progress and negative/positive behaviour), authentic tasks (activities that are genuine and purposeful. These can include real life shopping tasks, measuring a ball-park, designing a home, building a bridge or tower, writing about significant issues), checklists, scales or charts (identification and recording of students' achievement can be through rubric levels, letter grade or numerical value, or simply by acceptable/unacceptable), conferences (meetings between the student/parent/teacher and others where progress is checked and goals for growth are established and agreed upon), games (games are excellent opportunities for simulations and small and large group assessment), peer evaluation (assessment by students about one another's performance relative to stated criteria and program outcomes), portfolios (collections of student work that exhibit the students' efforts, progress and achievements in one or more areas), self-evaluations (student reflections about her/his own achievements and needs relative to program goals), simulations (the use of problemsolving, decision-making and role-playing tasks), student journals (personal records of, and responses to activities, experiences, strengths, interests and needs), teacher observations (regular, first-hand observations of students, documented by the teacher). (http://ais.act.edu.au/wpcontent/uploads/2016/02/Teachers-Guide-

To-Assessment.pdf). Almost all of these formative assessment strategies were utilized by the IT Instructors in their classroom to assess their student's performances.

\section{Feedback}

Results of assessment must be communicated to the learners or students in the form of feedback. According to Brookhart (2008), feedback is an essential component of the formative assessment process because it gives information to instructors and students about how students are doing relative to classroom learning goals. The purpose of assessment is to improve learning, inform teaching, help students achieve the highest standards they can and provide meaningful reports on students' achievement and it is

most effective when it is timely, perceived as relevant, meaningful and encouraging, and offers suggestions for improvement that are within a student's grasp (Brown, Bull, and Pendlebury, (1997).

The feedback made in the classroom during the learning process has been proven to increase learning and improve student outcomes. When given correctly, it guides the student in their learning process and gives them the direction they need to reach the target or goal of the lesson. Besides, it sends a message to the student that the instructor cares about the learning taking place. It also allows the student to become more engaged and involved in the classroom and learn to negotiate their learning (Webb, M., Gibson, D. \&Forkosh-Baruch, A. 2013) to give them access to meaningful 
representations of evidence and arguments about their achievements. These strategies could enable a vast range of measures to contribute to judgements of students' achievements supporting their learning in 21st- century contexts.

When the feedback is implemented properly, it can be very powerful because good feedback provides students information to understand where they are in their learning and what action to do to improve their performance. The moment that students feel they understand the what to do and why are they doing, they develop a feeling that they have control over their own learning. She further added that good feedback must contain information that can be used by the students, that is, the students must be able to hear and understand its message. She stressed that good feedback should be part of a classroom assessment environment in order for students to see constructive criticism as a good thing and understand that learning cannot occur without practice (Brookhart, 2008). This good feedback is also referred to as positive reinforcement while the negative feedback is a punishment. However, both reinforcement and punishment greatly affect learning, thus feedback is theorized to be effective if it is done properly.

Molloy and Boud (2013) found out that most of the researchers on feedback promote a constructivist approach rather than a didactic provision of performance information because it encourages learners and teachers to view feedback as a system of learning, rather than discreet episodes of instructors 'telling' learners about their performance. This constructivist framework positions the learner as having agency, and sets the learner on a path towards selfevaluation and self-regulation.

\section{Feedback Practices}

Accordingly, there are different types of feedback. These oral and written, formal and informal, formative and summative feedback, evaluative and descriptive feedback, and group/peer and self-feedback (State of New South Wales, Department of Education and Communities, 2015). The feedback that is done during a given task is oral feedback. Though it is less formal but a very powerful and effective tool because it can be given easily in a timely way. On the contrary, written feedback is given after the task is done. It contains students' records on their strength and weaknesses and ways to make their weakness a strength and to monitor these feedbacks, teachers may monitor the progress of the students. Moreover, a written feedback must be timely, understandable, and do-able for students to do the revisions. Also, it must describe whether students met the learning objectives, things that students need to improve and a suggestion on how to think of the answer by themselves.

The giving of feedback could be done during or after learning. In order absorb the feedback immediately by the students and for them to have some realization on their improvement feedback must be given during (formative feedback) the learning process. Comparing this to the feedback for learning or summative feedback, students will remember the feedback and may apply it to future task in which struggling students may find it more difficult to address. Generally, feedback during and after should focus on what is being learnt (learning intention) and how students should go about it (success criteria), provide information on how and why the student has or has not met the criteria and provide strategies to help the student to improve.

The feedback in the form of grades or brief general comments is called evaluative feedback. This provides some 
information about learning, but does not give complete information and guidance for students to improve. It more beneficial to good students but not for less able students because they will never chance to succeed. Giving of praises at the end of task as a form of feedback may create positive effect to the learning environment. But praises should be realistic to be more meaningful because it confirms the learner's own sense of reality.

The descriptive feedback offers students with complete and detailed but specific information about improving their learning. According to the Department

of Education and Communities in the State of New South Wales (2015), descriptive feedback is connected to the learning that is expected (Where am I going?), addresses faulty interpretations and lack of understanding (How am I going?), provides students with visible and manageable 'next steps' based on an assessment of the work at hand and an image of what 'good work looks like' so that they can begin to take on the responsibility of self-assessing and selfcorrecting. (What do I need to do to improve and how do I do it?).

In the case of Information Technology Instructors, not all of them have obtained education units so they should have at least a background on the concept and proper implementation of classroom assessment because they are not required to attend a teacher-training to teach in the College just like the Faculty of the College of Engineering (Subheesh, N. P., \&Sethy, S. 2020).Notwithstanding their strategies to be employed in the delivery of lessons, constructions of test items, conducting assessment and giving the students feedback on the results of assessment conducted though most of them exercise academic freedom since they are dealing with college students. However, problems may arise when giving of assessment does not conform with the goals or objectives being set and the giving of feedback is not individualized especially when assessment is performed individually, and is no longer relevant to the present situation of the students. As described by Siarova, Sternadel, \&Mašidlauskaitė, (2017), assessment for learning is providing direct support to students for improving their learning and teachers' practices. This only means that the very purpose of assessment is to help students determine their strengths and weaknesses so that they would know where they are from a set of standards and that teachers also know what to do in their instructions. In addition, providing qualitative feedback to students on their course content learning(Subheesh, N. P., \&Sethy, S. 2020) help themrecognise their strengths and weaknesses in learning course contents and overcome their weaknesses.

Utilizing various formative assessment strategies is the preference of the teacher but giving of feedback of the assessment done in the classroom must be channeled the soonest possible to the concerned learners or students. Both are found to be effective in dealing with learners' learning progress. However, the strategies used by teachers during instruction and their practices in providing information to the learners have not yet been explored.

With this study, the result would encourage instructors to provide learning feedback to the students and that latter are forced to reflect on the feedback provided by their instructors to patch up or strengthen their weakness and improve more their strengths in order to achieve the desired objectives by possessing the required skills. However, there are no studies focusing on the best practices of IT Instructors on their classroom assessment strategies and feedback practices. It is for this reason that this study was conceptualized so that 
concerned faculty may have basis in employing such strategies and they

may adopt the same practices as regard ways of providing information to the learners.

This study aimed to determine the classroom assessment strategies employed and best feedback practices by the Information Technology Instructors on the academic performance of IT Students. Specifically, it is intended to shed light to the extent to which practices in formative assessment are being implemented, investigated the extent to which the practices of giving feedback are used, explored the feedback practices by IT Instructors as assessed by IT students and tested the differences on the feedback styles of the IT Instructors based on their employment status and subject taught.

\section{METHODOLOGY}

This study made used of quantitative-descriptive research design and cross-sectional study. The cross-sectional design was used to determine the difference among the different groups of respondents regarding the extent of implementing feedback. The respondents were classified as students, Major-Subject Instructors and Non-major Instructors. The checklist on the assessment strategies and the feedback practices of the respondents were dealt quantitatively with description of the extent of their responses. It was conducted at the College of Information and Computing

\begin{tabular}{ll}
\hline $\begin{array}{l}\text { Scale } \\
\text { Range }\end{array}$ & $\begin{array}{l}\text { Qualitative } \\
\text { Description }\end{array}$ \\
\hline $1.00-1.74$ & Never Practice (NP) \\
\hline $1.75-2.49$ & $\begin{array}{l}\text { Seldom/Rarely Practice } \\
(\mathrm{RP})\end{array}$ \\
\hline $2.5-3.24$ & Often Practice (OP) \\
\hline $3.25-4.00$ & Always Practice (AP) \\
\hline
\end{tabular}

Sciences of Cagayan State University, Carig Campus, Tuguegarao City, Philippines through its Instructors and students in Academic Year 2019-2020. The study was only limited to the practices of the Instructors in conducting classroom formative assessment and the ways of providing feedback to their students along timing, amount, mode, audience and content of the feedback. Through Systematic and stratified sampling, 51 faculty members and 312 Information Technology Students were chosenfor the study.

The instrument used in collecting data was personally developed by the researcher adopting the concepts from "Effective feedback in the Classroom" under the Center for Innovation in Research and Teaching in Arizona, USA (https://cirt.gcu.edu/teaching3/tips/effectivef eed). It undergone validation by Language Professors and Computer Subject Professors. Aside from content validation, the reliability coefficient (Cronbach Alpha) was also computed and it has a coefficient of $85.76 \%$ in which according to George, D., \& Mallery, P. (2003) is "good". It was then administered to the respondents after integrating the suggestions, comments and recommendations of the experts.

The following scales and qualitative descriptions were utilized in the interpretation and discussion of analyzed data.

Data gathered were analyzed through a statistical software with the following statistical treatment: Mean and standard deviation were used to analyze the extent of practicing the assessment strategies, paired sample t-test was used to test the difference between the actual implementation through the students and the responses of the Instructors ANOVAwas used to analyze the 
differences of the extent of feedback practices by instructors and T-test to determine the difference on the extent of implementing feedback as assessed by Major-Subject Instructors, Non-Major Subject Instructors and Students who evaluated both their Major and Non-Major Subject Instructors. All of the respondents made used of the same questionnaire but slight modification of terms were made to fit the level of the respondents.

\section{RESULTS AND DISCUSSION}

\section{The Extent to which Practices in} Formative Assessment are being Implemented.

Table 1 presents the different strategies employed by the Instructors in both major and general education subjects to their classes in the college with the mean, standard deviation and the corresponding descriptive value.

Table 1.Assessment Strategies Employed by IT Instructors

\begin{tabular}{|c|c|c|c|}
\hline Assessment Strategies & Mean & $\begin{array}{c}\text { Std. } \\
\text { Deviation }\end{array}$ & $\begin{array}{c}\text { Descriptive } \\
\text { Value }\end{array}$ \\
\hline $\begin{array}{c}\text { Ready-made } \\
\text { quiz(textbook/reference } \\
\text { adoption-quiz) }\end{array}$ & 2.50 & .99 & $\begin{array}{c}\text { Practice } \\
\text { Often }\end{array}$ \\
\hline Computer-aided quiz & 2.14 & 1.02 & $\begin{array}{l}\text { Seldom } \\
\text { Practice }\end{array}$ \\
\hline Class Reporting & 2.03 & .72 & $\begin{array}{l}\text { Seldom } \\
\text { Practice }\end{array}$ \\
\hline Group Quiz & 2.49 & .83 & $\begin{array}{l}\text { Seldom } \\
\text { Practice }\end{array}$ \\
\hline Group Competition & 2.38 & 1.02 & $\begin{array}{l}\text { Seldom } \\
\text { Practice }\end{array}$ \\
\hline Group Project & 2.81 & .91 & $\begin{array}{c}\text { Practice } \\
\text { Often }\end{array}$ \\
\hline Group Discussion & 2.92 & .78 & $\begin{array}{c}\text { Practice } \\
\text { Often }\end{array}$ \\
\hline Class Recitation & 3.27 & .83 & $\begin{array}{l}\text { Always } \\
\text { Practice }\end{array}$ \\
\hline Paper Presentation & 2.57 & .97 & $\begin{array}{c}\text { Practice } \\
\text { Often }\end{array}$ \\
\hline Seatworks & 3.32 & .74 & $\begin{array}{l}\text { Always } \\
\text { Practice }\end{array}$ \\
\hline Assignments/homeworks & 3.22 & .78 & $\begin{array}{l}\text { Practice } \\
\text { Often }\end{array}$ \\
\hline
\end{tabular}




\begin{tabular}{cccc}
\hline Student-self evaluation & 2.59 & .82 & $\begin{array}{c}\text { Practice } \\
\text { Often }\end{array}$ \\
\hline Group/peer evaluation & 2.65 & .85 & $\begin{array}{c}\text { Practice } \\
\text { Often }\end{array}$ \\
\hline Teacher-made quiz & 3.62 & .59 & $\begin{array}{c}\text { Always } \\
\text { Practice }\end{array}$ \\
\hline Write-up projects & 2.78 & .93 & $\begin{array}{c}\text { Often } \\
\text { Practice }\end{array}$ \\
\hline Paired-work & 2.92 & .98 & $\begin{array}{c}\text { Often } \\
\text { Practice }\end{array}$ \\
\hline Portfolio & 2.31 & .99 & $\begin{array}{c}\text { Seldom } \\
\text { Practice }\end{array}$ \\
\hline Reflective Exercises & 2.47 & 1.07 & $\begin{array}{c}\text { Seldom } \\
\text { Practice }\end{array}$ \\
\hline
\end{tabular}

As gleaned from the table, the Instructors always practice the giving of class recitation to test the preparedness of students regarding the topic and was found effective in improving students' learning outocmes (Wibowo, Dwi\&Friana, Friana\&Pelipa, Emilia, 2018). Anotherassessment strategy that has always been used was the giving of seatwork in order to determine the extent of learning acquired by their students during lecture or discussion (Chilcoat, 1990) although not widely advocated by it is widely utilized. The last strategy that the Instructors have always been using in assessing their students' learning is the administration of teachermade quiz. This quiz is only given when the formative assessments have signaled good results as affirmed by $81.43 \%$ of the students to agreeing on its utilization as a learning tool (Sawarkar, Kuchewar, \& Desai, 2015).

However, such strategies like reflective exercises, portfolio, computeraided quiz, class reporting, group quiz, and group competition are seldomly practice, while they often use group project, group discussion, paper presentation, giving of assignments, conducting self or group evaluation, write-up projects and paired work.

Among these assessment strategies, the Instructors still make use of the traditional way of conducting formative assessment to their students.

Table 2.Assessment Strategies Employed by IT Instructors as Perceived by IT Students

\begin{tabular}{ccccccc}
\hline & \multicolumn{3}{c}{ Major Subject Instructors } & \multicolumn{3}{c}{$\begin{array}{c}\text { Non-Major Subject } \\
\text { Instructors }\end{array}$} \\
\cline { 2 - 7 } \begin{tabular}{c} 
Strategies \\
\cline { 2 - 6 }
\end{tabular} & Mean & SD & $\begin{array}{c}\text { Descriptive } \\
\text { Value }\end{array}$ & Mean & SD & $\begin{array}{c}\text { Descriptive } \\
\text { Value }\end{array}$ \\
\hline $\begin{array}{c}\text { Ready-made } \\
\text { quiz }\end{array}$ & 3.10 & .77 & Practice Often & 3.17 & .70 & Practice Often \\
\hline
\end{tabular}




\begin{tabular}{|c|c|c|c|c|c|c|}
\hline $\begin{array}{l}\text { Computer- } \\
\text { aided quiz }\end{array}$ & 3.12 & .85 & Practice Often & 2.68 & .87 & Practice Often \\
\hline Class Reporting & 2.74 & .88 & Practice Often & 2.99 & .80 & Practice Often \\
\hline Group Quiz & 2.71 & .87 & Practice Often & 2.87 & .79 & Practice Often \\
\hline $\begin{array}{c}\text { Group } \\
\text { Competition }\end{array}$ & 2.61 & .97 & Practice Often & 2.77 & .87 & Practice Often \\
\hline Group Project & 2.98 & .89 & Practice Often & 3.05 & .84 & Practice Often \\
\hline $\begin{array}{c}\text { Group } \\
\text { Discussion }\end{array}$ & 2.94 & .85 & Practice Often & 3.09 & .80 & Practice Often \\
\hline $\begin{array}{c}\text { Class } \\
\text { Recitation }\end{array}$ & 3.12 & 1.43 & Practice Often & 3.24 & .72 & Practice Often \\
\hline $\begin{array}{c}\text { Paper } \\
\text { Presentation }\end{array}$ & 2.75 & .94 & Practice Often & 2.97 & .80 & Practice Often \\
\hline Seatworks & 3.24 & .77 & $\begin{array}{l}\text { Always } \\
\text { Practice }\end{array}$ & 3.40 & 2.04 & $\begin{array}{l}\text { Always } \\
\text { Practice }\end{array}$ \\
\hline $\begin{array}{l}\text { Assignments/h } \\
\text { omeworks }\end{array}$ & 3.02 & .86 & Practice Often & 3.29 & .80 & $\begin{array}{l}\text { Always } \\
\text { Practice }\end{array}$ \\
\hline $\begin{array}{l}\text { Student-self } \\
\text { evaluation }\end{array}$ & 2.70 & .84 & Practice Often & 2.75 & .84 & Practice Often \\
\hline $\begin{array}{l}\text { Group/peer } \\
\text { evaluation }\end{array}$ & 2.64 & .87 & Practice Often & 2.72 & .85 & Practice Often \\
\hline $\begin{array}{l}\text { Teacher-made } \\
\text { quiz }\end{array}$ & 3.26 & .75 & $\begin{array}{l}\text { Always } \\
\text { Practice }\end{array}$ & 3.52 & 2.47 & $\begin{array}{l}\text { Always } \\
\text { Practice }\end{array}$ \\
\hline $\begin{array}{l}\text { Write-up } \\
\text { projects }\end{array}$ & 2.81 & .82 & Practice Often & 2.85 & .75 & Practice Often \\
\hline Paired-work & 2.91 & .79 & Practice Often & 2.92 & .79 & Practice Often \\
\hline Portfolio & 2.38 & .91 & $\begin{array}{l}\text { Seldom } \\
\text { Practice }\end{array}$ & 2.59 & .91 & Practice Often \\
\hline $\begin{array}{l}\text { Reflective } \\
\text { Exercises }\end{array}$ & 2.66 & .87 & Practice Often & 2.85 & .83 & Practice Often \\
\hline
\end{tabular}

The table (Table 2) above contains the assessment strategies employed by both the major and the non-major subject Instructors as perceived by the IT students together with their respective mean and descriptive values. This clearly shows that strategies such as seatwork and teacher-made quiz were always practice which reported the same by their Instructors while ready-made quiz, computer aided quiz, class reporting, group quiz, group competition, group project, group discussion class recitation, studentself-evaluation, group/peer evaluation paper presentation, project write ups, paired-work 
and the giving of reflective exercises as assessment techniques were often practice by all of their Instructors. However, their Instructors in Major and Non-major subjects have different frequencies in giving assignments, and portfolio assessments. Their Instructors in major subjects often practice the giving of assignments and seldom require the submission of portfolios while their non-major subject instructors always practice giving of seatwork and often ask for portfolio as means of assessing them.

Generally, it can be noted that most of the assessment strategies presented above were often practice by the Instructors of the College as they seem very important in assessing the performances of the students.

\section{The Extent of Feedback Practices of IT Instructors}

As the result shows in the table above, the Instructors have always practice the giving of feedback during the students' involvement in the discussion, they promptly return test papers, quiz papers, and homework papers or any outputs as forms of assessment. Hence, the giving of feedback to the students based from the result of assessment made in the classroom is done very timely. Being timely in providing feedback to students is most effective, relevant, meaningful and encouraging, and offers suggestions for improvement that are within their grasp. (Brown, Bull, and Pendleburry, 1997).Contrary to the findings of this study, Rahman, Babu and Ashrafuzzaman(2011) found out in their study that language teachers gave feedback on few occasions only and that was not regularly practiced.

Table 3.Feedback Practices by IT Instructors

Feedback Practices $\quad$ Mean Sd $\begin{gathered}\text { Descriptive } \\ \text { Value }\end{gathered}$

Timing

Giving of feedback right after assessment

3.19 .69 Practice Often

Giving of feedback during their involvement in the discussion

$3.35 .67 \quad$ Always

Practice

Promptly returning test papers, quiz papers, homework papers or any $\quad 3.43 .68 \quad$ Always outputs as forms of assessment

Practice

\section{Amount}

\begin{tabular}{lrr}
\hline Give feedback to correct major issues and misconceptions & 3.43 .64 & $\begin{array}{r}\text { Always } \\
\text { Practice }\end{array}$ \\
\hline $\begin{array}{l}\text { Give feedback to provide students a guide on where to go next and } \\
\text { what to focus on }\end{array}$ & 3.30 .61 & $\begin{array}{r}\text { Always } \\
\text { Practice }\end{array}$ \\
\hline $\begin{array}{l}\text { Select two or three main points in an assessment paper to comment } \\
\text { on }\end{array}$ & 2.8 .73 Practice Often \\
\hline $\begin{array}{l}\text { Comment both on their strengths and weaknesses } \\
\begin{array}{l}\text { Use written feedback when students need to be able to refer to the } \\
\text { feedback later }\end{array}\end{array}$ & 2.51 .03 Practice Often \\
\hline
\end{tabular}




\section{Mode}

\begin{tabular}{lllr}
\hline $\begin{array}{l}\text { Provide feedback orally when there is too much information for the } \\
\text { students to read or if the students does not read well }\end{array}$ & 3.80 .98 & $\begin{array}{r}\text { Always } \\
\text { Practice }\end{array}$ \\
\hline $\begin{array}{l}\text { Use interactive feedback to allow students to ask questions } \\
\text { Use visuals or demonstrations for visual learners and how-to types } \\
\text { of material }\end{array}$ & 3.22 .63 & Practice Often \\
\hline Use SMS to deliver my comments individually & 1.97 .94 & Practice Often \\
\hline
\end{tabular}

Message them privately whenever i give feedback

$2.11 \quad .89$

Seldom

Practice

Use social media such as messenger or the group chat

2.57 1.0 Practice Often

\section{Audience}

provide feedback individually

2.97 .82 Practice Often

Provide feedback to small groups of students

2.92 .79 Practice Often

Provide feedback to the entire or whole class

$3.30 .69 \quad$ Always

Practice

Give feedback to individuals when needed to address their own performance or learning

3.06 .74 Practice Often

Give feedback to groups or the whole class when most of the class is 3.22 .70 Practice Often missing a concept or needs reinforcement

\section{Content}

Comment is descriptive and specific enough to be valuable to the 3.24 .63 Practice Often student and provide them direction

Give feedback in a nonjudgmental and positive way 3.22 .62 Practice Often

Feedback is clear and i see to it that student understands it 3.24 .59 Practice Often

Feedback provides comparison with the other students through a rubric to determine where they stand with regard to mastery of content

With regards amount of feedback being given to students, Instructors always give feedback to correct major issues and misconceptions, so students will be guided on where to go next and what to focus on. Often do the instructors being selective on the points to ponder and writing comments on the strengths and weakness of their students for them to be able to ponder at a later time. As recommended by Subheesh, N. P., \&Sethy, S. (2020) in their study,providing qualitative feedback to students on their course content learning help them recognize their strengths and 
weaknesses in learning course contents and overcome their weaknesses.

Also, they always provide feedback to students orally or verbally when there is too much information for students to read. Giving verbal or oral feedback may be less formal but a very powerful and effective tool since it can be given easily in a timely way (State of New South Wales, Department of Education and Communities, 2015). They often use interactive feedback to allow students to ask questions and visuals or demonstrations for visual learners and howto types of material and the use of social media platforms. Seldom that they practice the giving of feedback through SMS to be sent to each student.

In addition, the recipient of feedback given by the Instructors is very necessary. As they do, they always give feedback to be address to the entire classbut often to individuals when needed to address their own performance or learning, small groups of students or even to the whole class especially when most of the students was missing a concept or needs reinforcement.

Finally, as to the content of feedback, the instructors often give a specific and descriptive comment to students for guidance in a nonjudgmental and positive manner so as not to apprehend the ego of the recipient provided that the feedback is clear and student understood it. They too often provide feedback as comparison to other students so that they know where they are at present along mastery of content.

While the Instructors in the College are very timely in providing feedback to their students, the study of Rahman, Babu and
Ashrafuzzaman (2011) made used of thematic analysis in analyzing the answers of their respondents from their interviews and found outthat feedback was given only on few occasions by language teachers both to the whole class and to the individual student through written comments or praises due to positive results of assessment conducted.

\section{Feedback Practices by IT Instructors as Assessed by IT Students.}

In table 4 , the feedback practices used by IT Instructors as perceived by IT Students is being presented with the corresponding mean value of each statement and its descriptive value for both Major subject and Non-major subject Instructors.

From the analysis, all of the Instructors often practice the giving of feedback students right after assessment and during their engagement in the discussion. However, they have different practices when it comes to their promptness of returning test papers or any outputs as forms of assessment. Further, students have also perceived that their instructors in both major and nonmajor subjects often practice the giving of feedback right after the assessment or during their involvement in class discussion. However, their major subject Instructors were always prompt in giving back their quiz papers or test papers while their nonmajor subjects Instructors did it often.

The major subjects Instructors often provide feedback to correct major issues and misconceptions from the students while the non-major subject Instructors have always been doing the same. In like 
Table 4.Feedback Practices Employed by IT Instructors as Perceived by IT Students

\begin{tabular}{|c|c|c|c|c|c|c|}
\hline \multirow[t]{2}{*}{ Practices } & \multicolumn{3}{|c|}{$\begin{array}{l}\text { Major Subject } \\
\text { Instructors }\end{array}$} & \multicolumn{3}{|c|}{$\begin{array}{l}\text { Gen. Ed Subject } \\
\text { Instructors }\end{array}$} \\
\hline & Mean & SD & DV & Mean & SD & DV \\
\hline Giving of feedback right after assessment & 3.05 & .80 & $\begin{array}{l}\text { Practice } \\
\text { Often }\end{array}$ & 3.07 & .75 & $\begin{array}{c}\text { Practice } \\
\text { Often }\end{array}$ \\
\hline $\begin{array}{l}\text { Giving of feedback during their involvement in } \\
\text { the discussion }\end{array}$ & 3.17 & 2.43 & $\begin{array}{l}\text { Practice } \\
\text { Often }\end{array}$ & 3.04 & .72 & $\begin{array}{l}\text { Practice } \\
\text { Often }\end{array}$ \\
\hline $\begin{array}{l}\text { Promptly returning test papers, quiz papers, } \\
\text { homework papers or any outputs as forms of } \\
\text { assessment }\end{array}$ & 3.34 & 2.57 & $\begin{array}{l}\text { Always } \\
\text { Practice }\end{array}$ & 3.30 & .76 & $\begin{array}{l}\text { Practice } \\
\text { Often }\end{array}$ \\
\hline $\begin{array}{l}\text { Give feedback to correct major issues and } \\
\text { misconceptions }\end{array}$ & 3.07 & .68 & $\begin{array}{l}\text { Practice } \\
\text { Often }\end{array}$ & 3.15 & 1.90 & $\begin{array}{l}\text { Always } \\
\text { Practice }\end{array}$ \\
\hline $\begin{array}{l}\text { Give feedback to provide students a guide on } \\
\text { where to go next and what to focus on }\end{array}$ & 3.10 & .77 & $\begin{array}{l}\text { Practice } \\
\text { Often }\end{array}$ & 3.14 & .73 & $\begin{array}{l}\text { Practice } \\
\text { Often }\end{array}$ \\
\hline $\begin{array}{l}\text { Select two or three main points in an } \\
\text { assessment paper to comment on }\end{array}$ & 2.76 & .77 & $\begin{array}{l}\text { Practice } \\
\text { Often }\end{array}$ & 2.97 & 2.49 & $\begin{array}{l}\text { Practice } \\
\text { Often }\end{array}$ \\
\hline $\begin{array}{l}\text { Comment both on their strengths and } \\
\text { weaknesses }\end{array}$ & 2.80 & .84 & $\begin{array}{l}\text { Practice } \\
\text { Often }\end{array}$ & 2.87 & .86 & $\begin{array}{c}\text { Practice } \\
\text { Often }\end{array}$ \\
\hline $\begin{array}{l}\text { Use written feedback when students need to be } \\
\text { able to refer to the feedback later }\end{array}$ & 2.68 & .87 & $\begin{array}{l}\text { Practice } \\
\text { Often }\end{array}$ & 2.75 & .86 & $\begin{array}{c}\text { Practice } \\
\text { Often }\end{array}$ \\
\hline $\begin{array}{l}\text { Provide feedback orally when there is too much } \\
\text { information for the students to read or if the } \\
\text { students does not read well }\end{array}$ & 3.08 & 2.46 & $\begin{array}{l}\text { Practice } \\
\text { Often }\end{array}$ & 2.97 & .78 & $\begin{array}{l}\text { Practice } \\
\text { Often }\end{array}$ \\
\hline $\begin{array}{l}\text { Use interactive feedback to allow students to } \\
\text { ask questions }\end{array}$ & 3.08 & .81 & $\begin{array}{l}\text { Practice } \\
\text { Often }\end{array}$ & 3.18 & .77 & $\begin{array}{c}\text { Practice } \\
\text { Often }\end{array}$ \\
\hline $\begin{array}{l}\text { Use visuals or demonstrations for visual } \\
\text { learners and how-to types of material }\end{array}$ & 3.07 & .84 & $\begin{array}{l}\text { Practice } \\
\text { Often }\end{array}$ & 3.18 & 1.94 & $\begin{array}{l}\text { Practice } \\
\text { Often }\end{array}$ \\
\hline Use SMS to deliver my comments individually & 2.36 & .99 & $\begin{array}{l}\text { Seldom } \\
\text { Practice }\end{array}$ & 2.35 & .98 & $\begin{array}{c}\text { Practice } \\
\text { Often }\end{array}$ \\
\hline $\begin{array}{l}\text { Message them privately whenever i give } \\
\text { feedback }\end{array}$ & 2.38 & 1.08 & $\begin{array}{l}\text { Seldom } \\
\text { Practice }\end{array}$ & 2.38 & 1.05 & $\begin{array}{l}\text { Seldom } \\
\text { Practice }\end{array}$ \\
\hline $\begin{array}{l}\text { Use social media such as messenger or the } \\
\text { group chat }\end{array}$ & 3.22 & .87 & $\begin{array}{l}\text { Practice } \\
\text { Often }\end{array}$ & 3.25 & 1.98 & $\begin{array}{l}\text { Always } \\
\text { Practice }\end{array}$ \\
\hline provide feedback individually & 2.95 & 1.42 & $\begin{array}{l}\text { Practice } \\
\text { Often }\end{array}$ & 2.84 & .85 & $\begin{array}{l}\text { Practice } \\
\text { Often }\end{array}$ \\
\hline Provide feedback to small groups of students & 2.84 & .82 & $\begin{array}{l}\text { Practice } \\
\text { Often }\end{array}$ & 2.87 & .83 & $\begin{array}{l}\text { Practice } \\
\text { Often }\end{array}$ \\
\hline
\end{tabular}




\begin{tabular}{lccccccc}
\hline Provide feedback to the entire or whole class & 3.17 & .79 & $\begin{array}{c}\text { Practice } \\
\text { Often }\end{array}$ & 3.22 & .80 & $\begin{array}{c}\text { Practice } \\
\text { Often }\end{array}$ \\
\hline $\begin{array}{l}\text { Give feedback to individuals when needed to } \\
\text { address their own performance or learning }\end{array}$ & 2.98 & .75 & $\begin{array}{c}\text { Practice } \\
\text { Often }\end{array}$ & 3.01 & .76 & $\begin{array}{c}\text { Practice } \\
\text { Often }\end{array}$ \\
\hline $\begin{array}{l}\text { Give feedback to groups or the whole class } \\
\text { when most of the class is missing a concept or } \\
\text { needs reinforcement }\end{array}$ & 3.16 & .74 & $\begin{array}{c}\text { Practice } \\
\text { Often }\end{array}$ & 3.15 & .76 & $\begin{array}{c}\text { Practice } \\
\text { Often }\end{array}$ \\
\hline $\begin{array}{l}\text { Comment is descriptive and specific enough to } \\
\text { be valuable to the student and provide them } \\
\text { direction }\end{array}$ & 3.11 & .71 & $\begin{array}{c}\text { Practice } \\
\text { Often }\end{array}$ & 3.123 & .68 & $\begin{array}{c}\text { Practice } \\
\text { Often }\end{array}$ \\
$\begin{array}{l}\text { Give feedback in a nonjudgmental and positive } \\
\text { way }\end{array}$ & 3.09 & .72 & $\begin{array}{c}\text { Practice } \\
\text { Often }\end{array}$ & 3.09 & .75 & $\begin{array}{c}\text { Practice } \\
\text { Often }\end{array}$ \\
\hline $\begin{array}{l}\text { Feedback is clear and i see to it that student } \\
\text { understands it }\end{array}$ & 3.11 & .74 & $\begin{array}{c}\text { Practice } \\
\text { Often }\end{array}$ & 3.12 & .79 & $\begin{array}{c}\text { Practice } \\
\text { Often }\end{array}$ \\
\hline $\begin{array}{l}\text { Feedback provides comparison with the other } \\
\text { students through a rubric to determine where } \\
\text { they stand with regard to mastery of content }\end{array}$ & 2.98 & .78 & $\begin{array}{c}\text { Practice } \\
\text { Often }\end{array}$ & 2.94 & .77 & $\begin{array}{c}\text { Practice } \\
\text { Often }\end{array}$ \\
\hline
\end{tabular}

manner, all of their instructors often give feedback to their students to serve as their guide on where to go next and what to focus on, and give comments both on their (students) strengths and weaknesses.

Based from the perceptions of the students' respondents, their Non-major subjects Instructors often send messages through SMS and seldom do they send feedback privately while these were seldom used by their Major subject Instructors.

Also, Instructors in the major and non-major subjects practiced often the giving of feedback to individuals, to small group or whole class if needed as assessed by their students and feedback received by students were often descriptive and specific enough for them to understand which would provide comparison with other students for them to know where they stand with reference to the assessment standards.

\section{Comparison on the feedback styles of the IT Instructors based on their employment status and subject classification.}

As reflected from table 6, it shows the differences on the feedback practices of the IT Instructors based from their employment status. As such, there is no significant difference on the feedback practices of the Permanent Instructors to that of the Part-time ones. This only shows that Instructors regardless of employment status in the College have practiced the same style of providing feedback to students regarding the results of assessment conductedThe table clearly illustrates that the Instructors holding permanent position have the same timing of giving feedback, the amount of feedback given to the students, the means of giving the feedback, the receiver of the feedback and the content of the feedback being provided for to the learners as that of the Part-time Instructors.

However, 
With this, it is very clear that the Instructors are just performing their obligations as mandated by their positions.

Table 6.Differences on the feedback practices of the IT Instructors according to Employment Status

\begin{tabular}{|c|c|c|c|c|c|c|}
\hline Factors & Employment Status & Mean & SD & F-value & Sig. & Remarks \\
\hline \multirow{2}{*}{ Timing } & Permanent & 3.30 & .48 & \multirow{2}{*}{0.29} & \multirow{2}{*}{0.60} & \multirow{2}{*}{ NS } \\
\hline & Part-Time & 3.40 & .62 & & & \\
\hline \multirow{2}{*}{ Amount } & Permanent & 3.06 & .48 & \multirow{2}{*}{0.73} & \multirow{2}{*}{0.40} & \multirow{2}{*}{ NS } \\
\hline & Part-Time & 2.90 & .59 & & & \\
\hline \multirow{3}{*}{ Mode } & Permanent & 2.91 & 1.06 & \multirow{3}{*}{0.98} & \multirow{3}{*}{0.33} & \multirow{3}{*}{ NS } \\
\hline & Part-Time & 2.58 & .49 & & & \\
\hline & Total & 2.82 & .90 & & & \\
\hline \multirow{2}{*}{ Audience } & Permanent & 3.16 & .59 & \multirow{2}{*}{1.69} & \multirow{2}{*}{0.20} & \multirow{2}{*}{ NS } \\
\hline & Part-Time & 2.88 & .57 & & & \\
\hline \multirow{2}{*}{ Content } & Permanent & 3.15 & .54 & \multirow{2}{*}{0.97} & \multirow{2}{*}{0.33} & \multirow{2}{*}{ NS } \\
\hline & Part-Time & 2.96 & .46 & & & \\
\hline
\end{tabular}

\section{NS-Not Significant}

\section{Comparison of Feedback Practices of IT Instructors Based from the Subject Taught}

Table 7.Differences on the feedback practices of the IT Instructors according to subject classification

\begin{tabular}{|c|c|c|c|c|c|c|}
\hline Factors & Subject Taught & Mean & $\mathrm{SD}$ & F-Value & Sig. & Remarks \\
\hline \multirow[t]{2}{*}{ Timing } & IT Subj. & 3.33 & .47 & \multirow{2}{*}{0.03} & \multirow{2}{*}{0.87} & \multirow{2}{*}{ NS } \\
\hline & Non-IT Subj & 3.30 & .64 & & & \\
\hline \multirow[t]{2}{*}{ Amount } & It Subj. & 2.94 & .50 & \multirow{2}{*}{2.20} & \multirow{2}{*}{0.15} & \multirow{2}{*}{ NS } \\
\hline & Non-IT Subj & 3.20 & .50 & & & \\
\hline \multirow[t]{2}{*}{ Mode } & IT Subj & 2.82 & 1.03 & \multirow{2}{*}{0.00} & \multirow{2}{*}{0.97} & \multirow{2}{*}{ NS } \\
\hline & Non-IT Subj & 2.83 & .54 & & & \\
\hline \multirow[t]{2}{*}{ Audience } & IT Sub & 2.96 & .57 & \multirow{2}{*}{3.84} & \multirow{2}{*}{0.06} & \multirow{2}{*}{ NS } \\
\hline & Non-IT Subj & 3.36 & .56 & & & \\
\hline Content & It Subj & 2.99 & .49 & 3.53 & 0.07 & NS \\
\hline
\end{tabular}




\section{$\begin{array}{lll}\text { Non-IT Subj } & 3.34 & .535\end{array}$}

\section{NS-Not Significant}

As reflected from table, it shows the differences on the feedback practices of the It Instructors according to subject classifications.

The table clearly illustrates that the Major Subject Instructors have the same timing of giving feedback, the amount of feedback given to the students, the means of giving the feedback, the receiver of the feedback and the content of the feedback being provided for to the learners as that of the Part-time Instructors. As such, there is no significant difference on the feedback practices of the Major Subject Instructors to that of the Non-Major Subject Instructors.

\section{Differences on the Feedback Practices of the IT Instructors and the IT Students}

Table 7 shows the result of testing the differences on the feedback practices as assessed by the Instructors and the perceptions of IT students. The result confirms that both set of respondents do not have significant differences. This means that what the students have actually seen and experienced with regards the feedback practices implemented by their Instructors is the same as what their Instructors have revealed in their actual doing. Hence, the students confirmed what their instructors have always been doing in giving feedback related to their class standing.

Table 7.Differences on the Feedback Practices as Confirmed by the Instructors and Students

\begin{tabular}{cccccccc}
\hline Paired & Mean & Std & $\begin{array}{c}\text { Std. Error } \\
\text { Mean }\end{array}$ & t-value & Df & $\begin{array}{c}\text { Sig. (2- } \\
\text { tailed) }\end{array}$ & Remarks \\
\hline Students-Faculty & -.04 & .31 & .07 & -.67 & 22 & .51 & NS \\
\hline
\end{tabular}

Differences on Feedback Practices According to Group Classification of Respondents

Table 8 shows the differences on feedback practices among the different group classifications of respondents. The different group of respondents are students who assessed the feedback practices of their Instructors in both Major and Non-major subjects, the Major Subject Instructors and the Non-major Subject Instructors. Using paired sample t-test, the differences on their practices were determined with the following pairings: Major subject Instructors as assessed by students against Major subject Instructors assessing themselves (pair 1), Non-major subject Instructors assessed by students against Non-major Instructors assessing themselves (pair 2), Major subject Instructors as assessed by Students against Major Subject Instructors assessing themselves (pair 3), and Nonmajor Subject Instructors against Major Subject Instructors. The comparison was made to test whether the differences are statistically significant or not.

Table 8. Differences on Feedback Practices According to Respondents' Group Classification 


\begin{tabular}{|c|c|c|c|c|c|c|c|c|}
\hline \multirow[b]{2}{*}{ Pairing } & \multirow{2}{*}{$\begin{array}{l}\text { Group } \\
\text { Classification } \\
\text { of } \\
\text { Respondents }\end{array}$} & \multicolumn{2}{|c|}{ Mean } & \multirow{2}{*}{$\begin{array}{c}\text { Std. } \\
\text { Deviation }\end{array}$} & \multirow[b]{2}{*}{$\begin{array}{c}\mathrm{t}- \\
\text { value }\end{array}$} & \multirow[b]{2}{*}{$\mathrm{df}$} & \multirow{2}{*}{$\begin{array}{l}\text { Sig. (2- } \\
\text { tailed) }\end{array}$} & \multirow[b]{2}{*}{ Remarks } \\
\hline & & Group & Gen & & & & & \\
\hline \multirow{2}{*}{ Pair 1} & $\begin{array}{l}\text { Major } \\
\text { Subject } \\
\text { Instructors } \\
\text { assessed by } \\
\text { Students }\end{array}$ & 2.983 & \multirow{2}{*}{-.003} & \multirow{2}{*}{0.345} & \multirow{2}{*}{-0.045} & \multirow{2}{*}{22} & \multirow{2}{*}{0.965} & \multirow{2}{*}{$\begin{array}{c}\text { Not } \\
\text { Significant }\end{array}$} \\
\hline & $\begin{array}{l}\text { major } \\
\text { Subject } \\
\text { Instructors } \\
\text { assessing } \\
\text { themselves }\end{array}$ & 2.968 & & & & & & \\
\hline \multirow{3}{*}{ Pair 2} & $\begin{array}{l}\text { Non-major } \\
\text { Subject } \\
\text { Instructors }\end{array}$ & 3.00 & \multirow{3}{*}{-0.174} & \multirow{3}{*}{0.294} & \multirow{3}{*}{-2.830} & \multirow{3}{*}{22} & \multirow{3}{*}{0.010} & \multirow{3}{*}{ Significant } \\
\hline & $\begin{array}{l}\text { Assessed by } \\
\text { Students }\end{array}$ & & & & & & & \\
\hline & $\begin{array}{l}\text { Non-major } \\
\text { Subject } \\
\text { Instructors } \\
\text { assessing } \\
\text { themselves }\end{array}$ & 3.17 & & & & & & \\
\hline \multirow{2}{*}{ Pair 3} & $\begin{array}{l}\text { Major } \\
\text { Subject } \\
\text { Instructors } \\
\text { assessed by } \\
\text { Students }\end{array}$ & 2.98 & \multirow{2}{*}{-0.014} & \multirow{2}{*}{0.078} & \multirow{2}{*}{-0.881} & \multirow{2}{*}{22} & \multirow{2}{*}{0.388} & \multirow{2}{*}{$\begin{array}{c}\text { Not } \\
\text { Significant }\end{array}$} \\
\hline & $\begin{array}{l}\text { Non-Major } \\
\text { Subject } \\
\text { Instructors } \\
\text { Assessed by } \\
\text { Students }\end{array}$ & 3.00 & & & & & & \\
\hline
\end{tabular}

\section{Non-major}

Subject

Pair 4

Instructors

\subsection{7}

\section{Major}

Subject

Instructors

As revealed by table 8 , there is no significant difference on the feedback practices based from the ratings provided by students to their Major Subject Instructors 
and to the ratings given by their Major Subject Instructors. This only means that the provision of feedback as revealed by their Major Subject Instructors is being reflected by the evaluation of their students. Moreover, there is no significant difference on the feedback practices on both the Major and Non-major Subject Instructors as assessed by the students.

On the other hand, there is a significant difference between the feedback practices as revealed by the ratings of students to their Non-major subject Instructors and the self-ratings made by the Non-major Instructors. The non-major subject Instructors rated their feedback practices higher than the students which makes the difference statistically significant. The ratings of both are not reflective of each other. This means that what the students have experienced was not a reflection of the practices implemented by their Non-major Instructors. Additionally, the self-evaluation ratings on feedback practices implemented by both the Major and Non-major Subject Instructors are significantly different. This significant difference can be attributed to the nature of paper works that the Non-major Subject Instructors have as compared to the Major Subject Instructors. The Non-Major subject Instructors have bulk of papers to check manually while the major-subject Instructors can have their students work checked immediately because most of the major subjects are offered with Laboratories so they can give feedback right away before their class ends. As it is being shown in table 8, self-evaluation of Non-major subject Instructors is higher than the Major subject Instructors making them both statistically significant.

\section{CONCLUSION}

This study brought out the best practices of College Instructors on assessment strategies they have used in their classroom and the extent of implementing feedback to students.

Regardless of employment status and subject taught to the IT Students in the College of Information and Computing Sciences, the best assessment practices of IT Instructors were the giving of class recitation, seatworks and teacher-made quiz as these were also confirmed by their students. Further, both the Major and NonMajor Subject Instructors have always practiced giving of feedback to their students by returning their papers after evaluating them to correct major issues or misconceptions immediately. Moreover, the employment status and subject handled of the Instructors do not hinder them to perform their job as this is mandated by their appointment. Both the permanent and parttime instructors have practiced the same style in providing feedback to their students regarding their performances.

However, the extent of implementing feedback to students by the Major-subject Instructors is significantly different with that of the Non-major Subject Instructors. When triangulated with the results made by students, the extent of implementing feedback by the Non-major Subject Instructors compared to that of the students is significantly different. With these differences, the Non-major Subject Instructors should look into their way of giving feedback with regards their students' academic performance.

Hence, there is a need to conduct an in depth study interrogating the feedback practices of College Instructors as these may greatly affect the academic successes of students.

\section{ACKNOWLEDGEMENT}

The author wishes to thank the members of the panel of reviewers during the campus inhouse research proposal presentation. Even 
if it was requested twice to present in different venues for its review and still not able to get funded, the author was more determined to push through with this study. Their insights were of great help for its improvement. Thanks a lot.

\section{REFERENCES}

[1] Brookhart, S. 2008. "How to Give Effective Feedback to your Students". Association for Supervision and Curriculum Development, USA.

[2] Brown, G., Bull, J., \& Pendlebury, M. 1997. Assessing student learning in higher education. London: Routledge. (5providingfeedback-for-student-learning.pdf)

[3] Center for Innovation in Research and Teaching. Effective Feedback in the Classroom. Grand Canyon University, Arizona. Retrieved from https://cirt.gcu.edu/teaching3/tips/effectivefe ed. Retrieved on August 15, 2018.

[4] De Lange, J. 1999. Framework for classroom assessment in mathematics. Fredenthal Institute and National Center for Improving Student Learning and Achievement in Mathematics and Science. Retrieved from www.fisme.science.uu.nl/catch/.../framewor k/de_lange_framework.doc

[5] Doran, R., Chan, F., \& Tamir, P. 2002. Science Educator's Guide to Assessment. National Science Teaching Association. Arlington, Virginia. United Book Press

[6] George, D., \& Mallery, P. 2003. SPSS for Windows step by step: A simple guide and reference. 11.0 update (4th ed.). Boston: Allyn \& Bacon
[7] Hilcoat, G. 1990. How to make seatwork more meaningful. Middle School Journal, 21(4), 2628. Retrieved December 20, 2020, from http://www.jstor.org/stable/23023758

[8] Keeley, P. \& Tobey, C. 2011. Mathematics formative assessment: 75 practical strategies for linking assessment, instruction, and learning. Virginia: National Council of Teachers of Mathematics.

[9] LearningTeaching Development Unit, LSN, Curtin University of Technology . "Providing feedback for student learning". Retrieved from https://evaluate.curtin.edu.au/local/docs/5pro viding-feedback-for-student-learning.pdf.

Retrieved on August 18, 2018.

[10] Molloy, E. and Boud, D. 2013. Feedback models for learning, teaching and performance. In Spector, J. M., Merrill, D., Elen, J. and Bishop, M.J. (Eds.) Handbook of Research on Educational Communications and Technology. Fourth Edition. Springer: New York, 413-424. DOI 10.1007/978-1-4614-3185-5_33

[11] National Council of Teachers of Mathematics (NCTM) 1995. Assessment standards for school mathematics. Virginia: National Council of Teachers of Mathematics, Inc.

[12] Stenmark, J. 1991. Mathematics assessment: myths, models, good questions, and practical suggestions. Virginia, USA. National Council of Teachers of Mathematics. NCTM, Inc.

[13] Sekaran, U. 2003 Research Methods for Business: A Skill-Building Approach. 4th Edition, John Wiley \& Sons, New York.

[14] Siarova, H.; Sternadel, D.; Mašidlauskaitè, R. 2017, 'Assessment 
practices for 21st century learning: review of evidence', NESET II report, Luxembourg: Publications Office of the European Union. doi: 10.2766/71491.

[15] Subheesh, N. P., \&Sethy, S. S. 2020. Learning through Assessment and Feedback Practices: A Critical Review of Engineering Education Settings. Eurasia Journal of Mathematics, Science and Technology Education, 16(3),

[16] Sawarkar, Gaurav \&Kuchewar, Vaishali \& Desai, Priti. 2015. Efficacy of Quiz as a Teaching and Learning Tool for First Year. 2. 92-95.

[17] Types of feedback. State of New South Wales, Department of Education and
Communities, 2015. Retreived from http://www.ssgt.nsw.edu.au/documents/1typ es_feedback.pdf.

. 19. Webb, M., Gibson, D. \&Forkosh-Baruch, A. 2013. "Challenges for Information Technology Supporting Educational Assessment". Retrieved from https://onlinelibrary.wiley.com/doi/abs/10.1 111/jcal.12033on August 18, 2018.

[19] Wibowo, Dwi\&Friana, Friana\&Pelipa, Emilia. 2018. Effect of Recitation Method to the Students' Interest and Learning Results. JurnalStudi Guru dan Pembelajaran. 1. 10.30605/jsgp.1.1.2018.22. 